\title{
Nutritional Approach and Treatment in Patients with Stroke, An Expert Opinion for Turkey
}

\author{
Inme Hastalarında Nütrisyonel Yaklaşım ve Tedavi, Türkiye için Uzman Görüşü
}

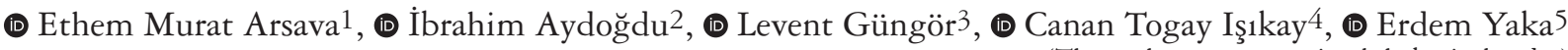

(The author names are in alphabetical order)

${ }^{1}$ Hacettepe University Faculty of Medicine, Department of Neurology, Ankara, Turkey

Ege University Faculty of Medicine, Department of Neurology, İzmir, Turkey

3Ondokuz Mayıs University Faculty of Medicine, Department of Neurology, Samsun, Turkey

${ }^{4}$ Ankara University Faculty of Medicine, Department of Neurology, Ankara, Turkey

5Dokuz Eylül University Faculty of Medicine, Department of Neurology, İzmir, Turkey

\begin{abstract}
Cerebrovascular diseases comprise the most common category of inpatient cases taken care of by neurologists. Dysphagia and malnutrition are not rare after stroke. It is strongly recommended for neurologists to screen and treat swallowing disturbances and malnutrition in stroke patients. However, present scientific literature lacks clear evidence with regards to nutritional treatment strategies for stroke patients. This review and recommendation paper is written with the aim to standardize nutritional screening and treatment algorithms during acute and chronic phases of cerebrovascular diseases and guide neurologists in Turkey for their daily practice.
\end{abstract}

Keywords: Stroke, nutrition, malnutrition, dysphagia

Öz

Beyin damar hastalıkları nöroloji uzmanlarının en çok yatırarak izlemek durumunda kaldığı hasta grubunu oluşturmaktadır. İnme sonrası disfaji ve beslenme bozukluğu nadir değildir. Akut dönemde ve taburculuk sonrasında inme hastalarının malnütrisyon ve yutma bozukluğu açısından izlemi ve tedavisi nöroloji uzmanları tarafından gerçekleştirilmelidir. Ancak mevcut literatür ve kaynaklarda inme hastalarının nütrisyonel tedavisi ile ilgili net veriler yoktur. Bu gözden geçirme ve öneri makalesi, Türkiye özelinde beyin damar hastalı̆̆ının akut ve kronik fazlarında nütrisyonel yaklaşım ve tedavi yöntemlerini standardize hale getirebilmek ve nöroloji uzmanlarına rehberlik etmesi amacıyla hazırlanmıştır.

Anahtar Kelimeler: İnme, nütrisyon, malnütrisyon, disfaji

\section{Introduction}

There is no specific evidence revealing how nutritional evaluation should be made in patients with cerebrovascular disease and which nutritional therapy should be preferred. The daily practice applied for these patients basically depends on scientific data obtained from general intensive care units (ICUs) and geriatric patient populations. Some countries and nutrition societies have developed their own national guidelines to compensate for this deficit. Five national specialists in the fields of stroke, neuro-intensive care, nutrition, and swallowing disorders collaborated to create basic proposals on the clinical significance of nutrition and dysphagia in patients with stroke, the diagnosis and treatment of malnutrition, and swallowing disorders, enteral nutrition products, application principles and complications, with consideration to national conditions.

A scientific search was performed in medical databases (PubMed and Embase) using the keywords "stroke, cerebrovascular disease, malnutrition, malnutrition screening, malnutrition assessment, nutrition, enteral nutrition, parenteral nutrition, oral supplements, dysphagia, dysphagia diagnosis, dysphagia screening, and dysphagia treatment". The resulting articles were evaluated

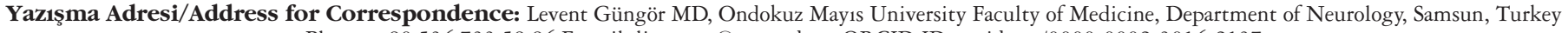
Phone: +905367335996 E-mail: ligungor@omu.edu.tr ORCID ID: orcid.org/0000-0002-3016-2137

Received/Geliş Tarihi: 21.01.2018 Accepted/Kabul Tarihi: 05.04.2018

${ }^{\circ}$ Copyright 2018 by Turkish Neurological Society

Turkish Journal of Neurology published by Galenos Publishing House. 
by each expert and a preliminary assessment was conducted via online communication. Consensus decisions on controversial and unclear issues were made following 3 meetings, each lasting 8 hours. The principles of nutritional assessment and treatment in patients with stroke were summarized in 19 questions and their relevant answers.

\section{Is malnutrition a common problem after stroke?}

Malnutrition is defined as "a state resulting from lack of uptake or intake of nutrition leading to altered body composition (decreased fat free mass) and body cell mass resulting with diminished physical and mental function, and impaired clinical outcome from disease". Malnutrition may also occur as the result of a disease state and ageing (1). Patients with stroke may lose their eating and drinking abilities due to disorders of consciousness, swallowing problems, postural instability, decreased mobilization, limitations in communication, fatigue, depression, and visuospatial deficits. Nearly $90 \%$ of patients with stroke have a risk of malnutrition (2).

Malnutrition rates reported in patients with stroke differ greatly according to the evaluation methods used and the patient population taken under consideration. The malnutrition rate determined among patients with acute stroke at admission is reported as 3.8-32\%; this ratio reaches up to $7.5-35 \%$ at the end of the second week of hospitalization. The prevalence of malnutrition within two-weeks after stroke is increased by nearly two-fold $(3,4,5,6,7,8,9,10,11,12,13,14,15)$. Malnutrition is very common in patients in rehabilitation centers, and malnutrition rates may increase up to $30-49 \%$ in the chronic phase $(16,17,18,19,20,21,22)$.

Malnutrition is not a rare event in the acute phase after stroke; its frequency increases gradually in subsequent weeks.

\section{What is the frequency of dysphagia after stroke?}

The frequency of dysphagia varies greatly according to the evaluation method used. The rate of dysphagia is 30$65 \%$ in the acute phase of ischemic and hemorrhagic stroke $(23,24,25,26,27,28)$. When a detailed examination is performed for the diagnosis of dysphagia by videofluoroscopy (VFS) or fiberoptic endoscopy, it increases up to $64-78 \%$ (29). Its frequency decreases to $22 \%$ in subsequent weeks (11). At the end of the sixth month, $13 \%$ of patients have not yet started to eat normally; dysphagia becomes permanent in nearly $3 \%$ of patients, and they require continuous enteral feeding $(25,26,30)$.

Dysphagia is a common problem following stroke, but recovers in the majority of patients with time.

\section{How is energy metabolism affected after stroke?}

Patients in the acute phase following stroke are not in a high hypermetabolic state, unlike patients with other critical diseases. In the first week after stroke, basal energy requirement is increased only by $7-26 \%$ above normal; it is not markedly elevated as in traumatic brain injury, sepsis or burns. Energy requirement at rest is found to be slightly increased in intracranial hemorrhage compared with ischemic stroke $(19,31,32,33)$.

After stroke, plasma catecholamine, cortisol, glucagon levels, interleukins, and acute phase reactants are found to be increased as a component of the acute stress response. This systemic response causes both a rapid catabolism and degradation of fat-free body mass, namely muscle tissue and fats. However, it is not clear how much this systemic response plays a role in the development of malnutrition.

In the case of fasting, all fat stores are degraded, and fatty acids are released to produce energy. Fatty acids cannot be used as an energy source for the brain because they cannot pass through the blood-brain barrier. Ketone bodies produced from fatty acids in the liver can pass through the blood-brain barrier, but they are not a good and effective energy source for neurons. If blood glucose is not replaced in patients with stroke whose oral intake is reduced, rapid muscle protein degradation starts in order to use amino acids as an energy source. This process, accompanied by other factors such as hormonal deficits, inflammation, and immobility, rapidly leads to a clinical picture with the potential of development of sarcopenia $(34,35)$.

Intestinal wall integrity depends on mesenteric blood flow and presence of nutrient products in the bowel lumen. Restriction of oral intake in a patient with stroke leads to rapid atrophy of intestinal villi and crypts, an increase in intestinal wall permeability, and translocation of pathogenic intestinal bacteria via the bowel wall. All of these processes culminate in an increased risk for sepsis $(36,37)$.

Patients with inadequate food intake after stroke start to lose their muscle tissue rapidly. Additionally, the lack of nutrients in the oral enteral route causes a risk of intestinal epithelial atrophy.

\section{Does development of dysphagia and malnutrition after stroke contribute to unfavorable outcomes?}

Mortality is higher in patients with malnutrition at admission (38). The Barthel index score on day 30 is lower, mortality is higher at the end of the first week, and complications are more frequent in patients whose nutritional parameters deteriorate after stroke. Duration and costs of hospitalization are higher in patients with malnutrition $(10,13,23)$. Patients who are not fed adequately and develop malnutrition during the period of hospitalization have worse prognosis at the end of the third month during followup $(11,14)$. This unfavorable effect of malnutrition continues till the sixth month after stroke (23).

The major complications of dysphagia related with stroke may be listed as aspiration and aspiration pneumonia (29), dehydration (39), prolonged hospitalization (40), longer rehabilitation period, and healthcare requirements (41). These complications cause a decrease in the physical and social well-being of patients with stroke, and the quality of life of the patient and their relatives (26). The presence of dysphagia increases the risk of malnutrition $(25,29,40,42,43,44)$.

Dysphagia and malnutrition after stroke increase mortality, morbidity, and costs. 


\section{Is nutritional support beneficial in patients with stroke?}

There is limited scientific evidence indicating that the correction of nutritional status and providing adequate energy intake in post-stroke patients has positive effects on clinical recovery $(15,45,46,47)$. This issue cannot be completely tested by a controlled clinical trial because there would evidently be an ethical problem with not feeding a group of post-stroke patients and feeding the other group. In line with studies and scientific evidence indicating that nutritional support in the general patient population has favorable effects on prognosis, it is generally accepted that the correction of nutritional parameters in post-stroke patients would also contribute positively to clinical prognosis.

\section{How is the nutritional state of stroke patients evaluated and followed up?}

The nutritional state and fluid intake of stroke patients should be evaluated at admission and at regular intervals thereafter, and the best nutritional plan should be prepared for patients (9). Clinical scales, anthropometric measurements, laboratory tests, and functional tests can be used to evaluate the nutritional state of stroke patients $(10,48)$. Some clinical scales have been developed for screening malnutrition, and others have been developed for both screening and evaluation; in other words, for defining the severity of malnutrition.

The screening tests developed to screen patients with malnutrition or at the risk of malnutrition are listed as Nutritional Risk Screening-2002 (NRS-2002), Mini Nutrition AssessmentShort Form (MNA-SF), Malnutrition Universal Screening Test (MUST), Malnutrition Screening Tool (MST) and Short Nutrition Assessment Questionnaire (SNAQ). Acute stroke patients, especially patients who cannot be fed orally, are under increased risk of malnutrition $(49,50)$. It is recommended that malnutrition should be intermittently screened during the chronic phase of stroke $(51,52,53,54)$. Screening tests can be performed in a short time by nurses or physicians.

There are three validated tests for evaluation of nutrition. These are the Subjective Global Assessment (SGA) (55), MNA (56), and 'informal evaluation' of nutritional state, which is the evaluation of patients by visual observation $(49,57)$. There is no standard screening and evaluation test for stroke patients. The most commonly used tests are MNA and SGA (52). SGA is an evaluation test for nutritional state developed to evaluate complication risks in patients scheduled for surgery (55). MNA is developed as a screening and evaluation tool in geriatric patients $(56,58)$. Both tests contain anthropometric measurements. MNA is a test with two steps; MNA-SF is used in malnutrition or malnutrition risk screening, and the complete test can assess the severity of malnutrition. The MNA and SGA tests show moderately significant correlations with biochemical parameters and anthropometric measurements in chronic stroke patients (for MNA $r=0.520$, for SGA $r=0.449$ ) (50). The power of these tests may be increased by biochemical markers (3).

Anthropometric measurements that may be used in nutritional state assessment are body weight, body mass index
(BMI), triceps skin thickness, and the arm and calf circumference measurements. The measurements of body weight and BMI are difficult in immobilized patients. Triceps skin thickness or midarm circumference may be measured in immobilized patients, but it should also be considered that these measurements may be misleading because of the presence of edema and atrophy in stroke patients. The hand grip test (with hand dynamometer) may be performed at the bedside as a functional test. However, none of these assessments are validated for the evaluation of nutritional status in patients with stroke.

Other investigations that may be used to evaluate body composition include bioelectrical impedance analysis, dual-energy $\mathrm{X}$-ray absorptiometry, computed tomography, ultrasonography, and magnetic resonance imaging.

There is no ideal biochemical marker to demonstrate the nutritional state of stroke patients. The cut-off values of biochemical parameters are debatable. Malnutrition rates differ greatly according to the methods used and cut-off values (49). Biochemical markers used during follow-up can be listed as albumin, pre-albumin, transferrin, retinol binding protein, serum iron, total cholesterol, leukocyte count, lymphocyte count, hemoglobin, and vitamin B12 and folic acid levels. There are also studies indicating that lower serum albumin levels $(<3.5 \mathrm{mg} /$ $\mathrm{dL})$ are related with poor prognosis after stroke $(59,60,61)$, and that albumin level is not related to the amount of protein and calorie intake (62). Blood levels of biochemical markers cannot be routinely used in the quantitative evaluation of malnutrition because their levels can change enormously with several factors such as patient age, acute stress, systemic inflammation and infections, hepatic function, catabolic processes, and accompanying diseases (63).

The diagnostic criteria for malnutrition were re-defined in 2015 by the European Society of Parenteral and Enteral Nutrition (Table 1) (1).

Stroke patients are generally at risk for malnutrition. Malnutrition that adversely affects prognosis should be evaluated starting from the acute phase, and a nutritional plan should be implemented accordingly.

There is no single method recommended to evaluate malnutrition in stroke patients; the MNA and SGA tests, which have been shown to be valid for other patient groups, can be used. Anthropometric measurements and laboratory investigations indicating body composition may be used in the diagnosis and follow-up of patients with malnutrition. There is no standard

\begin{tabular}{|c|c|}
\hline Definition 1 & $\mathrm{BMI}<18,5 \mathrm{~kg} / \mathrm{m}^{2}$ \\
\hline $\begin{array}{l}\text { Definition } 2 \\
\text { ( } 1+\text { one of the } \\
\text { remaining) }\end{array}$ & $\begin{array}{l}\text { 1. }>10 \% \text { involuntary weight loss at } \\
\text { any time or }>5 \% \text { weight loss in the } \\
\text { last } 3 \text { months } \\
\text { 2. }<70 \text { years old; BMI }<20 \mathrm{~kg} / \mathrm{m}^{2} \\
\geq 70 \text { years old; BMI }<22 \mathrm{~kg} / \mathrm{m}^{2} \\
\text { 3. Fat-free BMI; females }<15 \mathrm{~kg} / \mathrm{m}^{2} \text {, } \\
\text { males }<17 \mathrm{~kg} / \mathrm{m}^{2}\end{array}$ \\
\hline
\end{tabular}


biochemical test that can be used in the evaluation of the nutritional state of patients with stroke.

Nutrient and fluid intake of all stroke patients, especially those with problems of oral feeding, should be followed up during the acute phase, and their nutritional states should be evaluated weekly. Malnutrition screening and follow-up are also important in stroke patients during the chronic and rehabilitation phases. MUST, MST, NRS-2002, SNAQ or MNA-SF may be used as screening tests.

\section{Which tests are used for the screening and evaluation of dysphagia in stroke patients?}

The diagnosis of dysphagia can be made in stroke patients by bedside screening and clinical assessment tests. Specific equipment is essential for the advanced evaluation of dysphagia. During clinical examination, potential indicators of dysphagia include impaired consciousness, "National Institutes of Health Stroke Scale" score $>12$, aphasia, hypophonia, dysarthria, severe neurologic deficit, marked facial paralysis, decreased pharyngeal sensation and wet sound, cough, and change of voice after swallowing. On the other hand, risk factors for aspiration in patients with stroke are reported as presence of brainstem lesion, bihemispheric infarcts, accumulation of intraoral secretion, soft palate dysfunction, delay in swallowing reflex, marked facial paralysis, history of recurrent pulmonary infection, smoking and chronic obstructive pulmonary disorder, weak spontaneous cough, dysphonia, voice change, wet sound and wet coughing after swallowing. It is not always possible to diagnose aspiration by clinical examination. Nearly half of all patients with dysphagia aspirate, and pneumonia is reported to develop in one-third of these cases. Silent aspiration is the passage of swallowed material below the vocal cords without coughing. Under VFS, the incidence of aspiration is $30-51 \%$ in acute stroke patients, whereas silent aspiration is reported as $8-27 \%(64,65,66)$.

Early diagnosis of dysphagia is important in stroke patients to prevent complications, mainly pneumonia. It has been shown that the incidence of pneumonia is higher in stroke patients who are not screened for swallowing than in screened cases $(29,67,68)$.

The level of consciousness and cooperation of the patient, postural control (ability to sit straight with help), oral hygiene and secretion control, and voluntary cough should be evaluated before the screening test.

Screening tests should include water swallowing tests together with a clinical evaluation. Moreover, there are swallowing evaluation tests in which patients are given fluids of different textures and bolus amounts. Different evaluation methods such as the Toronto Bedside Swallowing Screening Test (69), Gugging Swallowing Screen (70), Mann Assessment of Swallowing Ability (MASA) and its MASA Modified Form (71), and the Barnes Jewish Hospital Stroke Dysphagia Screening (72) can be used to screen for dysphagia in stroke patients. The preferred swallowing screening test should be validated, reliable, and have high sensitivity. There is no study indicating the superiority of one of these tests over the other. There is no consensus or recommendation about which is the best test for stroke patients in systematic reviews and guidelines $(73,74,75)$.

The water contents and methodology differ among the most commonly used water swallowing tests. The water content changes between 5 and $100 \mathrm{~mL}$. Some procedures include re-swallowing boluses with a volume of 3 or $5 \mathrm{~mL}$, others include only sequential water swallowing from a glass, whereas others include both reswallowing of small amounts and sequential water swallowing. There is no consensus either in the optimal water swallowing test or ideal water amount for the screening of dysphagia $(76,77,78)$. However, the most commonly preferred method in the evaluation of swallowing is to start with small amounts and increase gradually (78).

Dysphagia screening should be performed in every stroke patient before the initiation of oral feeding and drug administration using a simple and valid bedside swallowing test, and the aspiration risk should be defined. This test may be performed by an experienced nurse or healthcare professional. The dysphagia screening test should be performed within the first 24 hours. The screening test may be repeated in the subsequent days if necessary, according to the neurologic condition of the patient. Oral feeding may be initiated carefully in patients who passed the test, but patients should be followed up thereafter for aspiration.

Weak palatal movement, dysarthria, abnormal voice, inadequacy of voluntary coughing, presence of abnormal pharyngeal sensation, observation of cough and voice change (wet voice) after swallowing $5 \mathrm{~mL}$ of water three times and $50 \mathrm{~mL}$ of water from a glass are high-sensitivity bedside clinical markers in dysphagia screening (Figure 1) (79). Monitorization of oxygen

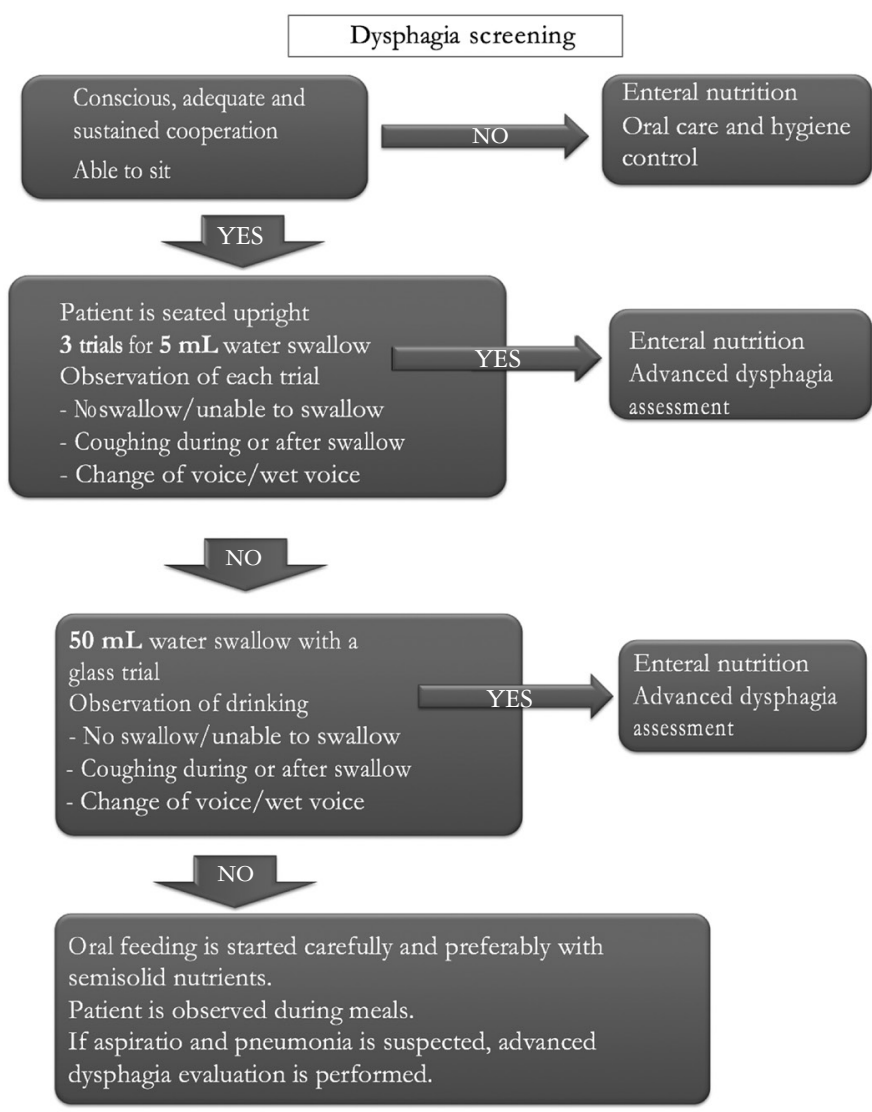

Figure 1. Recommended algorithm to determine the presence of dysphagia in stroke patients 
saturation from the finger during swallowing evaluation using a peripheral probe may increase the sensitivity of the screening test $(80,81,82)$.

In addition to a screening test, clinical evaluation of swallowing by an experienced physician or speech therapist may determine the presence of aspiration and dysphagia. In clinical assessment, the appropriate method and treatment options and possible risk of aspiration is determined in view of symptoms and signs. The oro-linguo-pharyngeal sensorimotor examination involves food and water swallowing tests with different consistencies. Although there is no generally accepted validated clinical swallowing evaluation method for stroke patients, a standardized protocol or clinical evaluation test developed by Logemann can be used (Annex 1) (83).

Patients who cannot pass the screening test, and those with dysphagia and aspiration risk lasting for longer than one week, may require further instrumental methods according to hospital and patient conditions. Advanced dysphagia evaluation is performed in patients with suspected silent aspiration or in patients who cannot pass screening tests, and is crtical for determining the consistency of foods, the way of swallowing therapy, and rehabilitation method. Therefore, it is recommended that further dysphagia evaluation should be performed by an experienced physician or speech therapist. VFS and fiberoptic endoscopic evaluation (FEES) may be used for this purpose. All phases of swallowing, aspiration, penetration or oropharyngeal residual materials can be shown radiologically using VFS. Its disadvantages include the requirement of complete patient cooperation, need for a sitting position, and a low dose of radiation. FEES is a swallowing evaluation performed using a short flexible endoscope. Patients swallow solutions with different consistencies and a mixture of food dyes. FEES is easy to perform by the bedside and available for follow-up, it is cheap and has no risk of irradiation. However, oral and esophageal phases are not visible during FEES, patients may feel uncomfortable, and it may cause irritation. Also, the requirement for experienced staff is another disadvantage $(84,85)$. Another test is the dysphagia limit, which determines the presence and level of dysphagia during neurologic practice by using EMG (86). Its disadvantages include the fact that patient should be in the sitting position, and should be cooperative (86).

All acute stroke patients should be screened for dysphagia before being given oral medication, food, and fluid. The risk of aspiration pneumonia may be decreased by formal screening test and the evaluation of dysphagia. A valid screening test should be performed by an experienced/trained healthcare professional. Dysphagia screening should be performed within the first 24 hours. Patients who pass the test are allowed oral feeding, but if the patient deteriorates, re-evaluation and follow-up for aspiration should be performed in all patients.

Patients who cannot pass the screening test are not allowed to be fed orally. It is suggested that patients should be re-evaluated at least twice per week for passage to oral feeding because it is highly possible for dysphagia to recover during the first weeks.

Further instrumental swallowing evaluation may be performed in patients who do not pass the screening test according to hospital and patient conditions. Enteral nutrition is started until VFS or FEES are performed. After VFS and FEES have been performed, a plan is prepared for enteral nutrition process or dysphagia treatment.

\section{How is dysphagia managed?}

The treatment of dysphagia should be managed by a team including a neurologist, physiotherapist, speech/language therapist, swallowing therapist, dietitian, occupational therapist, and a stroke nurse. Dysphagia treatment includes restorative methods, compensational techniques and adaptive methods $(84,87)$.

The aim of restorative methods is to facilitate improvement in swallowing function. Restorative methods include maneuvers and exercises to strengthen the swallowing muscles and oropharyngeal coordination. Sensorimotor exercises, tongue-chin exercises, chewing exercises, and laryngeal adduction exercises can be given as examples. Biofeedback systems, oral thermal, electrical, and vibratory sensory stimuli may also be used for this reason $(43,84)$. There is insufficient evidence to show whether transcutaneous/ neuromuscular electrical stimulation affects the function and safety (aspiration) of swallowing. There is evidence indicating that repetitive transcranial magnetic stimulation, which is one of the non-invasive cranial stimulation techniques, has positive effects on swallowing function, and decreases aspiration. The data for transcranial direct stimulation are inadequate; further studies are required (88). Consistent and adequate benefits have not been obtained in drug studies (nifedipine, cilostazol, cabergoline, angiotensin-converting enzyme inhibitors, amantadine) conducted on swallowing function, so further studies are also required with these as well (87).

The aim of compensation methods is to increase the safety of swallowing without correction of the underlying neuromuscular deficiency, and prevention of aspiration. Examples of postural manipulations are maneuvers such as "chin tuck", head flexion, and turning the head to the weak pharyngeal side (hemiplegic side). Multiple swallowing, forced swallowing, supraglottic swallowing, super supraglottic swallowing, the Mendelsohn maneuver, and laryngeal elevation are some examples of compensatory mechanisms $(43,84)$.

There are no prospective controlled studies demonstrating the efficacy of these methods in patients with swallowing disorders, and favorable effects are reported only from observational and anecdotal reports, and from personal experiences. There are studies reporting that long-term and high-intensity programs are better than short-term and low-intensity studies $(89,90)$.

Attempts have been made to provide patient adaptation to swallowing disorders by using adaptive methods, external support, and dietary regulation. Diet regulation, dietary enrichment, thickeners, enteral tube feeding, and percutaneous endoscopic gastrostomy (PEG) feeding are methods for adaptation $(43,84,91)$. Dietary regulation in dysphagic patients who can be fed orally is directed to adequate nutrient and fluid intake, and to decrease possible aspiration. There are studies indicating that thickened fluids are safer for swallowing and the risk of aspiration is less when compared with thin fluids. However, further studies are required to investigate the benefits of thickeners. Apart from these approaches, it has been shown that approaches for patient's oral hygiene and dental health have positive effects in stroke patients $(92,93)$.

The most ideal treatment for dysphagia should be performed by a team composed of neurologists, speech therapists, 
physiotherapists, dietitians, and stroke nurses. While teaching maneuvers and exercises for strengthening oropharyngeal coordination, helpful postures and compensation maneuvers should be shown to prevent aspiration. It is recommended that swallowing rehabilitation should be started in a cooperative stroke patient with dysphagia after one week.

Other treatment approaches are thickeners, diet modification (e.g., switching to soft diet and enriched diet), and initiation of enteral feeding without delay if daily calorie and protein requirements cannot be met via the oral route.

Applications directed to oral hygiene (oral and tooth care) should be performed in stroke patients to protect against aspiration pneumonia and other infections.

\section{Which stroke patients are initiated on enteral feeding?}

Enteral feeding should be initiated in every stroke patient who cannot be fed orally due to impaired consciousness, dysphagia or severe neurologic deficit, because they are highly prone to being at a high risk of developing malnutrition and pneumonia. Patients with deterioration in consciousness, lack of cooperation, aphasia, swallowing apraxia, $9^{\text {th }}-10^{\text {th }}$ and $12^{\text {th }}$ nerve palsies, and pseudobulbar palsy may require enteral nutrition. Nutritional tube feeding has been shown to reverse malnutrition under conditions where stroke patients cannot be orally fed despite the absence of dysphagia $(19,94)$. Enteral feeding may be initiated just for this time period because dysphagia due to stroke can improve in the first couple of weeks, and it may be switched to oral feeding after improvement of dysphagia (12,95).

Regardless of the underlying reasons, enteral nutrition should be employed in all stroke patients who cannot be fed orally, unless it is contraindicated.

\section{When is enteral nutrition initiated in stroke patients?}

The main data about the time to start enteral feeding in stroke patients were obtained from the randomized controlled clinical trial, Feed or Ordinary Diet (FOOD). In this study, which has some limitations, stroke patients who could not be fed orally were randomized into two groups; one with early enteral feeding as soon as possible, and the other with enteral feeding on the seventh day after stroke. Physicians were allowed to decide which type of enteral feeding (NG or PEG) would be administered. No statistically significant difference was found in the modified Rankin Score and mortality rates between early and late-onset enteral feeding groups (46).

Considering the negative effect of malnutrition in the prognosis of stroke patients, it is clear that protein and calorie targets should be reached as soon as possible. If only low-calorie fluids are infused intravenously in comatose stroke patients, the levels of protein and albumin decrease by $1.5 \mathrm{~g} / \mathrm{dL}$ and $1.2 \mathrm{~g} / \mathrm{dL}$, respectively (96). "Early enteral feeding", which means initiation of enteral nutrition within the first 24-48 hours of ICU admission, decreases infective complications and length of hospital stay in patients with traumatic brain injury and in medical ICU patients (97). If there is no severe metabolic disorder such as hemodynamic instability, diabetic ketoacidosis, or hepatic coma, severe nausea and vomiting or intestinal distention, then early enteral nutrition should be started. Even at lower doses, early enteral feeding has valuable effects on the preservation of intestinal mucosal integrity, and the continuation of barrier function and the immune system of the body. Trophic feeding (10-20 mL/hour) may be sufficient to prevent intestinal mucosal atrophy $(98,99,100)$.

Enteral feeding should be accepted as part of stroke management. Although there are no supportive data in randomized studies about stroke, in light of data obtained from other fields, enteral feeding should be initiated in acute stroke treatment as early as possible after hemodynamic stabilization is preserved. This time period should not be longer than $48-72$ hours.

\section{Which route is preferred for enteral feeding?}

Feeding tubes are used for enteral nutrition in stroke patients. The route of feeding tube may be nasogastric (NG), nasoduodenal (ND) or nasojejunal (NJ). If nasal tube insertion is impossible, then the oral route (orogastric/oroenteral) can be used. No studies have tested the superiority of these routes over each other during the acute phase in stroke patients. Although the use of postpyloric feeding has been shown to decrease aspiration risk in critical patients in some studies, this has not been corroborated in other studies $(101,102,103)$. As a result, postpyloric feeding is the primary objective; however, enteral feeding should not be delayed if the tube stays in the gastric area.

The location of the feeding tube may be confirmed using chest $\mathrm{X}$-ray or by checking the $\mathrm{pH}$ of aspiration material via the tube. If the $\mathrm{pH}$ of the aspirated liquid is below 5 (shown by using litmus paper), the tube is supposed to be inserted in the stomach. However, $\mathrm{pH}$ measurement alone may cause faulty results if the tube is in the esophagus or when drugs affecting gastric acidity are used. The diameter of commonly used feeding tubes is 6-10 French (Fr); if the diameter of the inserted tube is $8 \mathrm{Fr}(1 \mathrm{Fr}=0.33$ $\mathrm{mm})$, then it is suitable. Feeding should not be performed using a NG drainage catheter. Radiopaque tubes should be preferred because they are easily detected in chest and abdominal X-rays. Displacement of nasoenteral tubes is the most common issue mentioned in studies. It is recommended that a nasal loop should be used to prevent this (104).

It has not been shown that early PEG insertion after stroke is superior to nasoenteric approach in survival and neurologic recovery. It is reported that PEG insertion within the first week after stroke was only helpful to reach nutritional targets, and it decreased ventilator-associated pneumonia risk in one study (105). Long-term NG nutrition has risks such as displacement of tube, traumatic insertion, pressure ulcers, gastric and duodenal ulcers, aspiration and pneumonia, and inadequate feeding or dehydration. It is believed that such problems are less frequently encountered in feeding with PEG $(98,99,106)$.

As a standard, enteral feeding is initiated by using tubes reaching the enteral system via the nasal route. Initially, NG or ND accesses are targeted. A NJ tube may be used in patients with a high risk of aspiration and recurrent aspirations. If enteral feeding requirement is longer than four weeks, then opening PEG is recommended. No definite benefit has been shown in the opening of PEG during the early phase. However, if it is considered from 
the beginning that dysphagia and enteral feeding will last for a long period, early PEG insertion may be reasonable.

\section{How are calorie, protein, and fluid} requirements of stroke patients calculated, and what is the dose of nutritional product?

Indirect calorimetry is the best way to calculate the daily calorie need of a stroke patient. Indirect calorimetry depends on the hypothesis that all oxygen taken into the body is used to oxidize energy sources in the body, and all carbon dioxide produced during this time interval is released through expiration. The energy content that an individual needs at rest is calculated using a closed spirometry system, which captures the oxygen used and carbon dioxide produced in a defined time interval. Measured volumes are converted to the daily calorie requirement by using the Weir formula. It is a non-invasive and cheap method. It calculates the metabolic rate with an error rate of $1 \%$. There are different indirect calorimetric devices with different designs $(107,108)$. However, formulas obtained from test results of hospitalized patients (Penn State, Ireton-Jones, Swinamer) or healthy volunteers (Harris-Benedict, Mifflin-St Jeor) are preferred because there are difficulties with its practical use in ICUs and hospitalized patients. All these equations may be affected by various confounders such as obesity, asthenia, treatments given, body temperature, and comorbid conditions (109). The superiority of energy calculation considering ideal body weight by using height and sex (20-30 $\mathrm{kcal} / \mathrm{kg} /$ day) to the above-mentioned formulas is its simplicity. It can be used in stroke patients.

There is no specific study investigating the initiation dose of enteral feeding, or the duration to reach the calorie target. It is recommended that enteral feeding is started at an infusion rate of $20 \mathrm{~mL} /$ hour, and if there are no complications the infusion rate can be increased by $10-20 \mathrm{~mL} /$ hour every $8-12$ hours to reach the targeted calories. To provide efficient enteral feeding, $80 \%$ of the targeted calorie and protein contents should be given within the first 48-72 hours.

The daily protein requirement is calculated as $1-1.5 \mathrm{~g} / \mathrm{kg} /$ day. Protein requirement, especially in patients who require ICU hospitalization, may reach up to $2 \mathrm{~g} / \mathrm{kg} / \mathrm{day}$. Protein is an important macronutrient for wound healing, supporting immune functions, and preservation of BMI. However, it has not been shown that protein-supplemented enteral solutions provide superior nutritional conditions in comparison to that in stroke patients who received standard enteral solutions (102). There are no data proving the efficacy of serum albumin, pre-albumin, transferrin, and C-reactive protein measurements to follow up the adequacy of protein support $(103,110)$.

Daily fluid requirement is calculated as $30 \mathrm{~mL} / \mathrm{kg} /$ day. To reach this target, and prevent dehydration, it should be remembered that there is $69-86 \%$ free water in nutritional products.

Indirect calorimetry is the most reliable method to calculate calorie requirement, but calorie calculations considering ideal body weight is a frequently used practical method. Daily calorie requirements in stroke patients may be calculated as $20-30 \mathrm{kcal} /$ $\mathrm{kg}$. It is aimed to start nutrition at $20 \mathrm{~mL} / \mathrm{hour}$, and to reach the target dose at least within 48-72 hours.

\section{Which enteral product to choose?}

Enteral nutritional products are divided into four groups as polymeric, oligomeric, elemental, and disease-specific modified products. Standard polymeric products are preferred in all stroke patients. Osmolarities vary between 265 and 320 mOsm. Energy content is provided by $15-20 \%$ of protein, $30-35 \%$ of fat, and $49-54 \%$ of carbohydrate. A standard $500 \mathrm{~mL}$ product contains 20 $\mathrm{g}$ protein, 16-20 g fat, and 60-70 g carbohydrate. One $\mathrm{mL}$ of a standard polymeric product provides $1 \mathrm{kcal}$ of energy, and its $\mathrm{pH}$ value is between 6.5 and 7.0 .

The protein content is increased to $29-31 \mathrm{~g}$, the fat content is increased to $20-31 \mathrm{~g}$, and the carbohydrate content is increased to 93-100 $\mathrm{g}$ in high-energy products, so that $1 \mathrm{~mL}$ of the formulation can provide 1.5-2.0 kcal energy. High-energy products have a high osmolarity and low fluid content. They can be used in patients who should have fluid restriction. Physicians should be cautious about the dehydration of patients while administering these products. These products may cause osmotic diarrhea due to the high osmolarity.

The protein content in every $500 \mathrm{~mL}$ of high protein products is increased to $32-34 \mathrm{~g}$, such that $20-22 \%$ of energy is provided from proteins. The high protein ratio causes the high osmolarity value to reach $290-474 \mathrm{mOsm}$. It helps to meet the protein requirement with a lower calorie content.

In high-fiber products, non-digested and non-absorbed fiber ratios are increased without changing the ratios of protein, fat, and carbohydrate. The osmolarity of these products varies between 210-360 mOsm.

Disease-specific products are used for special conditions by changing their contents. Products high in branched chained amino acid (valine, leucine, isoleucine), low in aromatic acids (tyrosine, phenylalanine, methionine, tryptophan) are manufactured for hepatic failure, whereas protein-restricted and essential amino acid and histidine only-containing products are developed for renal failure. Use of these products may not be convenient for patients undergoing dialysis. For diabetic patients, there are products with a low carbohydrate ratio, increased protein and fat ratios, and those containing monounsaturated fatty acids. Their osmolarities are high. These products are more commonly recommended in diabetic patients without blood glucose regulation rather than for routine use. There are no consistent or adequate data about the clinical benefits of disease-specific products.

Elemental and semi-elemental products are low-molecularweight compounds necessitating minimal digestion and providing almost complete absorption. Fats constitute only $1-12 \%$ of the energy content. They decrease pancreatic, biliary, and intestinal secretions, and the amount of feces. They may be used in diseases that deteriorate digestion or absorption capacity.

Modular products are used in addition to nutrients to change the general energy and nutritional composition, and they are comprised of only glucose polymers, protein, or lipids. They are preferred in patients who require fluid restriction, with electrolyte imbalance, or in need of specific nutrients $(106,111,112,113)$.

Although scientific evidence is inadequate, depending on practical long-term experience, the most commonly employed nutritional products in stroke patients are polymeric standard 
formulas. Diabetic products may be administered if blood glucose levels are uncontrolled; fiber-rich products can be given in patients with diarrhea and constipation. High-calorie products can be administered in patients with fluid restriction or whose energy requirements cannot be provided. Products high in protein can be given to patients with protein deficiency.

\section{How should enteral feeding be administered?}

Enteral tube feeding may be performed by either continuous infusion through special pumps or by intermittent bolus administration. There are data obtained from studies conducted on patients in general ICUs about intermittent feeding or continuous infusion. These data indicate that continuous infusion decreases the risk of aspiration, pneumonia, and diarrhea, decrease contamination risk of products, and prevent spending for unnecessary assistant healthcare professional workforce. Therefore, continuous infusion is preferred in hospitalized stroke patients. Intermittent enteral feeding may be preferred in patients who are mobilized, at the stage of discharge, and in those who are planned to receive enteral feeding at home. However, before switching to intermittent feeding, the patient should have reached targeted calorie levels with continuous infusion $(106,114,115,116)$.

The head of the bed should be raised to 30-45 degrees to decrease the risk of aspiration during infusion of nutritional product. Routine use of prokinetic agents is not recommended. There are no data indicating that they decrease the risk or increase tolerance of the risk of aspiration pneumonia. Prokinetic agents (metoclopramide, domperidone) can be used under conditions such as gastric distention, nausea, vomiting, regurgitation, and constipation. Prokinetic agents can also be used to facilitate passage of a feeding tube through the postpyloric region $(106,112,113)$.

Oral hygiene performed at least twice daily using oral antiseptics such as chlorhexidine decreases the risk of pneumonia in stroke patients with an enteral feeding requirement. Bacterial contamination of aspirated saliva is important in respiratory tract infections associated with aspiration. Therefore, oral hygiene should be provided carefully in stroke patients $(117,118)$.

Although no studies have been conducted on stroke patients investigating gastric residual volume (GRV), it has been shown in studies conducted in the ICU that there is no correlation between GRV and the incidence of pneumonia and aspiration. In addition, it is not recommended to perform GRV follow-up during routine practice because it causes interruption of enteral feeding, it prevents reaching protein and calorie goals, and it may lead to contamination of enteral products. GRV measurement is not valid in the presence of post-pylorically located enteral feeding tubes $(119,120,121,122,123)$.

GRV follow-up is only performed in patients who cannot tolerate enteral nutrition, and have nausea, vomiting, distention, and decreased intestinal sounds.

Continuous enteral nutrition is preferred in acute stroke patients who are followed up in the hospital. It is not recommended to routinely check $G R V$ or initiate prokinetic agents. Oral hygiene decreases the risk of pneumonia and it should be performed twice daily.

\section{What are the complications of enteral nutrition in stroke patients, and how are they treated?}

Diarrhea: This is defined as a daily number of defecations of more than three times with more than $250 \mathrm{~mL}$ volume. During enteral nutrition, it may arise due to bolus administration, rapid or high-dose infusion, the use of products with high osmolarities, cold solutions, bacterial contamination, gastrointestinal infection, and malabsorption. The first thing to do in the presence of diarrhea is to check the enteral nutrition scheme of the patient. Decreasing infusion rate, switching to products with lower osmolarity or products high in fiber are the first-step treatment options. Drugs that may cause diarrhea such as antibiotics, prokinetic agents, and antacids should be reviewed.

The presence of fecal incontinence should also be considered. Causes of infectious diarrhea should be ruled out by performing a fecal culture and direct microscopic examination. If there is a suspicion of malabsorption, the patient should be referred to the appropriate departments. If the problem persists despite these precautions, they should be switched to parenteral feeding.

Nausea-vomiting: If nausea and vomiting develop during enteral nutrition, first the infusion rate is decreased. Sedative drugs should be discontinued. Prokinetic agents may be used.

Constipation: Immobilization, pain and stress, previous abdominal surgery, accompanying systemic diseases such as diabetes and pancreatitis, drugs such as opioids, anticholinergics, erythromycin, and benzodiazepine may decrease gastrointestinal motility. It should be ensured that adequate hydration is preserved in constipated patients with nausea and vomiting. Products high in insoluble fiber content may be started. Discontinuation of drugs causing hypomotility, and dealing with problems of immobilization may solve the problem. If the condition continues, stool softeners or intestinal stimulants may be required. In resistant cases, mechanical and paralytic ileus should be ruled out. If intestinal passage cannot be provided enteral nutrition should be discontinued, and it should be switched to parenteral feeding.

Refeeding syndrome: This is observed when high-calorie nutrients are administered rapidly in patients who have been malnourished for a long-time. Refeeding syndrome presents with impaired consciousness, deteriorated medical status, or seizures. Signs of cardiac failure may develop. Hypophosphatemia, hypomagnesemia, hypokalemia, and fluid retention may develop. When refeeding syndrome develops, electrolyte deficiencies and circulation volume should be carefully corrected. Thiamin (50-250 $\mathrm{mg}$ ) should be administered, especially during glucose infusion. Thiamin support may be required until the patient is stabilized. Intravenous replacement is performed with $40-80 \mathrm{mmol} / \mathrm{day}$ of phosphate, $8-16 \mathrm{mmol} / \mathrm{day}$ of magnesium, and $80-120 \mathrm{mmol} /$ day of potassium. Diuretics should be used carefully because they may increase the intensity of hypokalemia. At most, 50-75\% of the targeted calorie should be administered to patients who have developed refeeding syndrome. It is important to prevent this fatal complication in patients at risk of developing refeeding syndrome by starting enteral nutrition at very small amounts, and gradually increasing the volume $(118,124,125,126)$.

Metabolic complications of feeding with NG tube, PEG, and enteral nutrition are given in Tables 2,3 , and 4 . 


\section{How are oral drugs administered in patients fed by enteral route?}

There may be problems in enterally fed patients who should receive oral drugs. Parenteral forms of drugs should be used in these patients, especially when they are hospitalized. Tablets are suspended in $30 \mathrm{~mL}$ of water after crushing. They are given through tubes using 50-cc syringes. If required, contents of capsulated drugs may be emptied in hot water and the granules should be given through PEG tubes. Oral drugs should never be added into the feeding bag. Crushed tablets or opened capsule contents may have physical and chemical interaction with the feeding tube wall and decrease the administered dose, so drug absorption may change. When slow-release forms are crushed, this characteristic is lost, and drug bolus is administered at high dose. Different drugs should not be mixed in the same syringe. Before and after drug administration with a syringe, the feeding tube should be washed with 15-50 cc of warm water. Thirty minutes before drug administration through a feeding tube, enteral feeding should be discontinued, and it should be re-started 30 minutes after drug administration $(127,128,129,130,131,132,133)$.

Rules for administering some drugs that are commonly used in neurologic practice through enteral tubes are given in Annex 2.

\begin{tabular}{|c|c|}
\hline Gastrointestinal (30-38\%) & Mechanical (2-10\%) \\
\hline Nausea-vomiting & Agitation, irritability \\
\hline Esophageal reflux & Rhinitis, otitis, parotitis \\
\hline Diarrhea & Epistaxis \\
\hline Gastrointestinal bleeding & $\begin{array}{l}\text { Nasopharyngitis, } \\
\text { esophagitis }\end{array}$ \\
\hline Abdominal cramps & $\begin{array}{l}\text { Nasopharyngeal edema, } \\
\text { ulcer }\end{array}$ \\
\hline $\begin{array}{l}\text { Abdominal distention and } \\
\text { constipation }\end{array}$ & $\begin{array}{l}\text { Malposition or } \\
\text { displacement of tube }\end{array}$ \\
\hline Perforation & Aspiration and edema \\
\hline Malabsorption & $\begin{array}{l}\text { Esophageal erosion and } \\
\text { stricture }\end{array}$ \\
\hline Elevated hepatic enzymes & Obstruction of tube \\
\hline
\end{tabular}

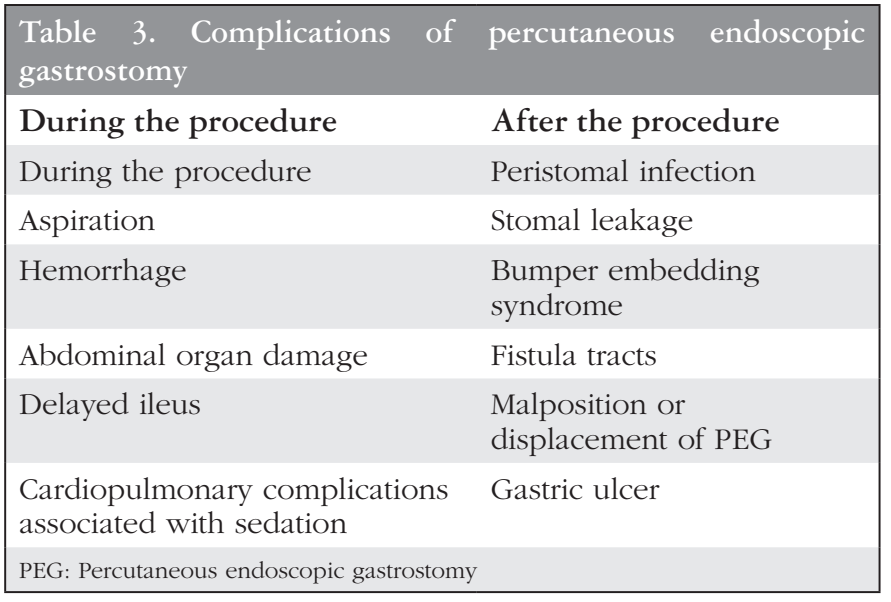

\section{How are enterally fed patients followed up?}

Follow-up in the first week is especially important in patients who are fed enterally. Urine volume should always be surveyed. Close blood glucose follow-up is performed. Urea, creatinine, electrolytes and liver enzymes should be surveyed every day whereas, calcium, magnesium and phosphorus are monitored twice a week. Body weight should be checked at reasonable time intervals $(106,114,115,116)$.

Dysphagia should be evaluated twice in the first week, once a week in weeks 1-4, in the first month after discharge, and 3-6 months after the first follow-up to test whether patients still require enteral nutrition because it may improve. Enteral tubes are withdrawn in patients with safe swallowing.

\section{In which stroke patients should oral} nutritional support products be used?

Oral nutritional support products are sterile compounds formulized as liquid, semisolid or powder forms, which are prepared to be given orally and include different amounts of micro and macronutrients. Studies have been conducted about their use in different clinical settings to support daily calorie and nutrient intake, and these studies highlighted positive effects in terms of functional (e.g., increased grasp strength), nutritional (e.g., weight gain, achieving daily protein and calorie targets), and clinical (e.g.,

Table 4. The most common metabolic complications and their solution methods for enteral feeding

\begin{tabular}{|c|c|c|}
\hline Complication & Cause & Solution \\
\hline Hyponatremia & $\begin{array}{l}\text { Excessive } \\
\text { hydration }\end{array}$ & $\begin{array}{l}\text { Change the product } \\
\text { Restrict fluids }\end{array}$ \\
\hline Hypernatremia & $\begin{array}{l}\text { Inadequate fluid } \\
\text { intake }\end{array}$ & $\begin{array}{l}\text { Increase amount of } \\
\text { free fluid }\end{array}$ \\
\hline Dehydration & $\begin{array}{l}\text { Diarrhea } \\
\text { Inadequate fluid } \\
\text { intake }\end{array}$ & $\begin{array}{l}\text { Investigate causes of } \\
\text { diarrhea } \\
\text { Increase free fluid } \\
\text { intake }\end{array}$ \\
\hline Hyperglycemia & $\begin{array}{l}\text { Excessive } \\
\text { energy intake } \\
\text { Inadequate } \\
\text { insulin }\end{array}$ & $\begin{array}{l}\text { Evaluate energy } \\
\text { intake } \\
\text { Adjust insulin dose }\end{array}$ \\
\hline Hypokalemia & $\begin{array}{l}\text { Refeeding } \\
\text { syndrome } \\
\text { Diarrhea }\end{array}$ & $\begin{array}{l}\text { Potassium } \\
\text { replacement } \\
\text { Investigate causes of } \\
\text { diarrhea }\end{array}$ \\
\hline Hyperkalemia & $\begin{array}{l}\text { Excessive } \\
\text { potassium } \\
\text { intake } \\
\text { Renal failure }\end{array}$ & Change the product \\
\hline Hypophosphatemia & $\begin{array}{l}\text { Refeeding } \\
\text { syndrome }\end{array}$ & $\begin{array}{l}\text { Phosphate } \\
\text { replacement } \\
\text { Decrease } \\
\text { administered calorie } \\
\text { amount }\end{array}$ \\
\hline Hyperphosphatemia & Renal failure & Change the product \\
\hline
\end{tabular}


decrease in pressure ulcer incidence and mortality, shortening of hospitalization duration) endpoints, especially in geriatric individuals with malnutrition through the use of oral nutrition support products $(134,135,136,137,138)$.

A limited number of studies have been conducted to investigate whether there are similar effects in stroke patients. The most important of these was a multicenter, randomizedcontrolled study named FOOD, which was performed on a total of 4023 patients (46). In this study, oral nutritional support was not shown to be significantly effective on mortality and functional outcome in stroke patients. This study had certain methodologic drawbacks in design, such as the evaluation of nutritional state only by clinical observation in $63 \%$ of patients, and underrepresentation of malnourished patients, constituting only $8 \%$ of the overall cohort. In this subset of patients with malnutrition, there was evidence for a non-significant decrease in mortality and functional dependency. Overall, taking into consideration other additional studies, which are very heterogeneous in terms of the products used and study design, various nutritional goals were attained by using oral nutritional support products, but no consistent clinical benefit was shown in stroke patients $(15,16,46,139)$.

Use of oral nutritional support products on a routine basis is not recommended in stroke patients. In stroke patients with malnutrition or risk of malnutrition where adequate protein and calorie requirements cannot be provided by normal nutritional schemes, oral nutritional support products can be initiated, if oral intake is safe. Oral nutritional support treatment may contribute to the improvement of nutritional parameters in this patient group. However, there is no consistent evidence indicating their positive effects on clinical endpoints.

\section{In which stroke patients should total} parenteral nutrition (TPN) be administered?

There are no studies regarding the effects of TPN specifically in stroke patients; therefore, the use of TPN in these patients can be deduced in view of data obtained from other clinical settings. Parenteral nutritional is not clearly superior to enteral nutrition in terms of mortality, functional outcome, and length of hospitalization in patients with functional gastrointestinal tracts. It is not considered as the first-line nutritional treatment because of its possible complications and cost. Parenteral treatment is an option when enteral nutrition is contraindicated or treatment targets are not reached by enteral nutrition $(140,141,142)$.

Parenteral nutrition is not recommended routinely in stroke patients.

Parenteral nutrition should be considered only when oral or enteral nutritional treatments are contraindicated or these treatments cannot provide the required treatment targets.

If TPN has to be initiated, every measure should be taken to prevent treatment related complications, mainly hyperglycemia and infection, and nutritional support should be switched to oral or enteral regimens with the shortest time interval possible.

A nutritional approach algorithm for stroke patients is given in Annex 3 together with three prescription examples regarding basic nutritional requirements (Annex 4).
Acknowledgement: We wish to thank Professor Rainer Dziewas for his guidance during the preparation of the expert opinion.

Ethics

Peer-review: Externally peer-reviewed.

Authorship Contributions

Concept: E.M.A., İ.A., L.G., C.T.I., E.Y., Design: E.M.A., İ.A., L.G., C.T.I., E.Y., Data Collection or Processing: E.M.A., İ.A., L.G., C.T.I., E.Y., Analysis or Interpretation: E.M.A., İ.A., L.G., C.T.I., E.Y., Literature Search: E.M.A., İ.A., L.G., C.T.I., E.Y., Writing: E.M.A., İ.A., L.G., C.T.I., E.Y.

Conflict of Interest: No conflict of interest was declared by the authors.

Financial Disclosure: The study investigators and investigator meetings were sponsored by Nutricia Türkiye.

\section{References}

1. Cederholm T, Bosaeus I, Barazzoni R, et al. Diagnostic criteria for malnutrition - An ESPEN consensus statement. Clin Nutr 2015;34:335340 .

2. Nishioka S, Okamoto T, Takayama M, et al. Malnutrition risk predicts recovery of full oral intake among older adult stroke undergoing enteral nutrition: Secondary analysis of a multicentre survey (the APPLE patients study). Clin Nutr 2016;36:1089-1096.

3. Crary MA, Carnaby-Mann GD, Miller L, Antonios N, Silliman S. Dysphagia and nutritional status at the time of hospital admission for ischemic stroke. J Stroke Cerebrovasc Dis 2006;15:164-171.

4. Crary MA, Humphrey JL, Carnaby-Mann G, Sambandam R, Miller L, Silliman S. Dysphagia, nutrition, and hydration in ischemic stroke patients at admission and discharge from acute care. Dysphagia 2013;28:69-76.

5. Davis JP, Wong AA, Schluter PJ, Henderson RD, O'Sullivan JD, Read SJ. Impact of premorbid undernutrition on outcome in stroke patients. Stroke 2004;35:1930-1934.

6. Axelsson K, Asplund K, Norberg A, Alafuzoff I. Nutritional status in patients with acute stroke. Acta Med Scand 1988;224:217-224.

7. DePippo KL, Holas MA, Reding MJ, Mandel FS, Lesser ML. Dysphagia therapy following stroke: a controlled trial. Neurology 1994;44:1655-1660.

8. Unosson M, Ek AC, Bjurulf P, von Schenck H, Larsson J. Feeding dependence and nutritional status after acute stroke. Stroke 1994;25:366-371.

9. Mosselman MJ, Kruitwagen CL, Schuurmans MJ, Hafsteinsdottir TB. Malnutrition and risk of malnutrition in patients with stroke: prevalence during hospital stay. J Neurosci Nurs 2013;45:194-204.

10. Martineau J, Bauer J, Isenring E, Cohen S. Malnutrition determined by the patient-generated subjective global assessment is associated with poor outcomes in acute stroke patients. Clin Nutr 2005;24:1073-1077.

11. Zhang J, Zhao X, Wang A, et al. Emerging malnutrition during hospitalisation independently predicts poor 3-month outcomes after acute stroke: data from a Chinese cohort. Asia Pac J Clin Nutr 2015;24:379-386.

12. Dennis M. Nutrition after stroke. Br Med Bull 2000;56:466-475.

13. Davalos A, Ricart W, Gonzalez-Huix F, et al. Effect of malnutrition after acute stroke on clinical outcome. Stroke 1996;27:1028-1032.

14. Yoo SH, Kim JS, Kwon SU, Yun SC, Koh JY, Kang DW. Undernutrition as a predictor of poor clinical outcomes in acute ischemic stroke patients. Arch Neurol 2008;65:39-43.

15. Gariballa SE, Parker SG, Taub N, Castleden CM. Influence of nutritional status on clinical outcome after acute stroke. Am J Clin Nutr 1998;68:275281.

16. Aquilani R, Scocchi M, Iadarola P, et al. Protein supplementation may enhance the spontaneous recovery of neurological alterations in patients with ischaemic stroke. Clin Rehabil 2008;22;1042-1050.

17. Hama S, Kitaoka T, Shigenobu M, et al. Malnutrition and nonthyroidal illness syndrome after stroke. Metabolism 2005;54:699-704. 
18. Foley NC, Martin RE, Salter KL, Teasell RW. A review of the relationship between dysphagia and malnutrition following stroke. J Rehabil Med 2009;41:707-713.

19. Finestone HM, Greene-Finestone LS, Wilson ES, Teasell RW. Malnutrition in stroke patients on the rehabilitation service and at follow-up: prevalence and predictors. Arch Phys Med Rehabil 1995;76:310-316.

20. Westergren A, Karlsson S, Andersson P, Ohlsson O, Hallberg IR. Eating difficulties, need for assisted eating, nutritional status and pressure ulcers in patients admitted for stroke rehabilitation. J Clin Nurs 2001;10:257-269.

21. Poels BJ, Brinkman-Zijlker HG, Dijkstra PU, Postema K. Malnutrition, eating difficulties and feeding dependence in a stroke rehabilitation centre. Disabil Rehabil 2006;28:637-643.

22. Lim HJ, Choue R. Nutritional status assessed by the Patient-Generated Subjective Global Assessment (PG-SGA) is associated with qualities of diet and life in Korean cerebral infarction patients. Nutrition 2010;26:766-771.

23. Gomes F, Emery PW, Weekes CE. Risk of malnutrition is an independent predictor of mortality, length of hospital stay, and hospitalization costs in stroke patients. J Stroke Cerebrovasc Dis 2016;25:799-806.

24. Gordon C, Hewer RL, Wade DT. Dysphagia in acute stroke. Br Med J (Clin Res Ed) 1987;295:411-414.

25. Smithard DG, O'Neill PA, England RE, et al. The natural history of dysphagia following a stroke. Dysphagia 19971;12:188-193.

26. Mann G, Hankey GJ, Cameron D. Swallowing function after stroke: Prognosis and prognostic factors at 6 months. Stroke 1999;30:744-748.

27. Flowers HL, Silver FL, Fang J, Rochon E, Martino R. The incidence, cooccurrence, and predictors of dysphagia, dysarthria, and aphasia after firstever acute ischemic stroke. J Commun Disord 2013;46:238-248.

28. Mourao AM, Lemos SM, Almeida EO, Vicente LC, Teixeira AL. Frequency and factors associated with dysphagia in stroke. Codas 2016;28:66-70.

29. Martino R, Foley N, Bhogal S, Diamant N, Speechley M, Teasell R. Dysphagia after stroke: incidence, diagnosis, and pulmonary complications. Stroke 2005;36:2756-2763.

30. Ojo $\mathrm{O}$, Brooke $\mathrm{J}$. The use of enteral nutrition in the management of stroke. Nutrients 2016;8.

31. Bardutzky J, Georgiadis D, Kollmar R, Schwarz S, Schwab S. Energy demand in patients with stroke who are sedated and receiving mechanical ventilation. J Neurosurg 2004;100:266-271.

32. Esper DH, Coplin WM, Carhuapoma JR. Energy expenditure in patients with nontraumatic intracranial hemorrhage. JPEN J Parenter Enteral Nutr 2006;30:71-75.

33. Frankenfield DC, Ashcraft CM. Description and prediction of resting metabolic rate after stroke and traumatic brain injury. Nutrition 2012;28:906-911.

34. Hasselbalch SG, Knudsen GM, Jakobsen J, Hageman LP, Holm S, Paulson OB. Brain metabolism during short-term starvation in humans. J Cereb Blood Flow Metab 1994;14:125-131.

35. Scherbakov N, Sandek A, Doehner W. Stroke-related sarcopenia: specific characteristics. J Am Med Dir Assoc 2015;16:272-276.

36. Jacobi SK, Odle J. Nutritional factors influencing intestinal health of the neonate. Adv Nutr 2012;3:687-696.

37. Wernerman J. Feeding the gut: how, when and with what, the metabolic issue. Curr Opin Crit Care 2014;20:196-201.

38. FOOD Trial Cooloboration. Poor nutritional status on admission predicts poor outcomes after stroke: observational data from the FOOD trial. Stroke 2003;34:1450-1456.

39. Altman KW, Yu GP, Schaefer SD. Consequence of dysphagia in the hospitalized patient: impact on prognosis and hospital resources. Arch Otolaryngol Head Neck Surg 2010;136:784-789.

40. Guyomard V, Fulcher RA, Redmayne O, Metcalf AK, Potter JF, Myint PK. Effect of dysphasia and dysphagia on inpatient mortality and hospital length of stay: a database study. J Am Geriatr Soc 2009;57:2101-2106.

41. Maeshima S, Osawa A, Miyazaki Y, Seki Y, Miura C, Tazawa Y, et al. Influence of dysphagia on short-term outcome in patients with acute stroke. Am J Phys Med Rehabil 2011;90:316-320

42. Foley N, Teasell R, Salter K, Kruger E, Martino R. Dysphagia treatment post stroke: a systematic review of randomised controlled trials. Age Ageing 2008;37:258-264.
43. Sura L, Madhavan A, Carnaby G, Crary MA. Dysphagia in the elderly: management and nutritional considerations. Clin Interv Aging 2012;7:287298.

44. Arnold M, Liesirova K, Broeg-Morvay A, et al. Dysphagia in acute stroke: Incidence, burden and impact on clinical outcome. PLoS ONE 2016;11:e0148424.

45. Nii M, Maeda K, Wakabayashi H, Nishioka S, Tanaka A. Nutritional improvement and energy intake are associated with functional recovery in patients after cerebrovascular disorders. J Stroke Cerebrovasc Dis 2016;25:57-62.

46. Dennis MS, Lewis SC, Warlow C; FOOD Trial Collaboration. Routine oral nutritional supplementation for stroke patients in hospital (FOOD): a multicentre randomised controlled trial. Lancet 2005;365:755-763.

47. Nyswonger GD, Helmchen RH. Early enteral nutrition and length of stay in stroke patients. J Neurosci Nurs 1992;24:220-223.

48. Shen HC, Chen HF, Peng LN, et al. Impact of nutritional status on longterm functional outcomes of post-acute stroke patients in Taiwan. Arch Gerontol Geriatr 2011;53:149-152

49. Foley NC, Salter KL, Robertson J, Teasell RW, Woodbury MG. Which reported estimate of the prevalence of malnutrition after stroke is valid? Stroke 2009; 40:66-74.

50. Kim Y, Kim CK, Jung S, Ko SB, Lee SH, Yoon BW. Prognostic importance of weight change on short-term functional outcome in acute ischemic stroke. Int J Stroke 2015;10(Suppl A100):62-68.

51. Wang J, Luo B, Xie Y, Hu HY, Feng L, Li ZN. Evaluation methods on the nutritional status of stroke patients. Eur Rev Med Pharmacol Sci 2014; 18:3902-3907.

52. Peters L, O'Connor C, Giroux I, Teasell R, Foley N. Screening and assessment of nutritional status following stroke: results from a national survey of registered dietitians in Canada. Disabil Rehabil 2015:1-5.

53. National Collaborating Centre for Chronic Conditions (UK). Stroke: National Clinical Guidelines for the Diagnosis and Initial Management of Acute Stroke and Transient Ischaemic Attack (TIA). London: Royal College of Physicians, 2008

54. Ha L, Hauge T, Spenning AB, Iversen PO. Individual, nutritional support prevents undernutrition, increas $\neg$ es muscle strength and improves QoL among elderly at nutritional risk hospitalized for acute stroke: a ran $\neg$ domized, controlled trial. Clin Nutr 2010;29:567-573.

55. Baker JP, Detsky AS, Wesson DE, et al. Nutritional assessment: a comparison of clinical judgement and objective measurements. $\mathrm{N}$ Engl J Med 1982;306:969-972.

56. Guigoz Y, Vellas B, Garry P. The Mini Nutritional Assessment: a practical assessment tool for grading the nutritional state of elderly patients. Facts Res Gerontol 1994;4:15-59.

57. Mead GE, Donaldson L, North P, Dennis MS. An informal assessment of nutritional status in acute stroke for use in an international multicentre trial of feeding regimens. Int J Clin Pract 1998;52:316-318.

58. Vellas B, Guigoz Y, Garry PJ. The Mini Nutritional Assessment: MNA. Nutrition in the elderly 2nd ed. Paris: Serdi, 1994.

59. Gariballa SE, Parker SG, Sinclair AJ, Castleden CM. Serum albumin predicting functional outcome following acute stroke. Proceedings of the British Congress of Gerontology, Manchester: Newton Mann Ltd,1996.

60. Gariballa SE, Parker SG, Taub N, Castleden CM. Nutritional status of hospitalized acute stroke patients. Br J Nutr 1998;79:481-487.

61. Aptaker RL, Roth EJ, Reichhardt G, Duerden ME, Levy CE. Serum albumin level as a predictor of geriatric stroke rehabilitation outcome. Arch Phys Med Rehabil 1994;75:80-84.

62. Akner G, Cederholm T. Treatment of protein-energy malnutrition in chronic nonmalignant disorders. Am J Clin Nutr 2001;74:6-24.

63. Gariballa SE, Sinclair AJ. Assessment and treatment of nutritional status in stroke patients. Postgrad Med J 1998;74:395-399.

64. Kidd D, Lawson J, Nesbitt R, MacMahon J. Aspiration in acute stroke: A clinical study with videofluoroscopy. QJ Med 1993;86:825-829.

65. Horner J, Massey EW, Riski JE, Lathrop DL, Chase KN. Aspiration following stroke: clinical correlates and outcome. Neurology 1988;38:1359-1362. 
66. Ramsey D, Smithard D, Kalra L. Silent aspiration: What do we know? Dysphagia 2005;20:218-225.

67. Hinchey JA, Shephard T, Furie K, et al. Formal dysphagia screening protocols prevent pneumonia. Stroke 2005;36:1972-1976.

68. Lakshminarayan $\mathrm{K}$, Tsai AW, Tong X, et al. Utility of dysphagia screening results in predicting poststroke pneumonia. Stroke 2010;41:2849-2854.

69. Martino R, Silver F, Teasell R, et al. The Toronto Bedside Swallowing Screening Test (TOR-BSST): development and validation of a dysphagia screening tool for patients with stroke. Stroke 2009;40:555-561.

70. Trapl M, Enderle P, Nowotny M, et al. Dysphagia bedside screening for acutestroke patients: the Gugging Swallowing Screen. Stroke 2007;38:29482952.

71. Antonios N, Carnaby-Mann G, Crary M, et al. Analysis of a physician tool for evaluating dysphagia on an inpatient stroke unit: the modified Mann Assessment of Swallowing Ability. J Stroke Cerebrovasc Dis 2010;19:4957.

72. Edmiaston J, Connor LT, Steger-May K, Ford AL. A simple bedside stroke dysphagia screen, validated against videofluoroscopy, detects dysphagia and aspiration with high sensitivity. J Stroke Cerebrovasc Dis 2014;23:712716.

73. Schepp SK, Tirschwell DL, Miller RM, Longstreth WT Jr. Swallowing screens after acute stroke: a systematic review. Stroke 2012;43:869-871.

74. O’Horo JC, Rogus-Pulia N, Garcia-Arguello L, Robbins J, Safdar N. Bedside diagnosis of dysphagia: a systematic review. J Hosp Med 2015;10:256-265.

75. Donovan NJ, Daniels SK, Edmiaston J, et al. Dysphagia screening: state of the art: International Stroke Conference 2012. Stroke 2013;44:24-31.

76. Osawa A, Maeshima S, Tanahashi N. Water-swallowing test: screening for aspiration in stroke patients. Cerebrovasc Dis 2013;35:276-281.

77. Suiter DM, Leder SB. Clinical utility of the 3-ounce water swallow test. Dysphagia 2008;23:244-250.

78. Brodsky MB, Suiter DM, González-Fernández M, et al. screening accuracy for aspiration using bedside water swallow tests: A systematic review and meta-analysis. Chest 2016;150:148-163.

79. Daniels SK, Anderson JA, Willson PC. Valid items for screening dysphagia risk in patients with stroke: a systematic review. Stroke 2012;43:892-897.

80. Smith CH, Logemann JA, Colangelo LA, Rademaker AW, Pauloski BR. Incidence and patient characteristics associated with silent aspiration in the acute care setting. Dysphagia 1999;14:1-7.

81. Lim SH, Lieu PK, Phua SY, et al. Accuracy of bedside clinical methods compared with fiberoptic endoscopic examination of swallowing (FEES) in determining the risk of aspiration in acute stroke patients. Dysphagia 2001;16:1-6.

82. Chong MS, Lieu PK, Sitoh YY, Meng YY, Leow LP. Bedside clinical methods useful as screening test for aspiration in elderly patients with recent and previous strokes. Ann Acad Med Singapore 2003;32:790-794.

83. Logemann JA, Veis S, Colangelo L. A screening procedure for oropharyngeal dysphagia. Dysphagia 1999;14:44-51.

84. Bakheit AM. Management of neurogenic dysphagia. Postgrad Med J 2001;77:694-699.

85. Ramsey DJ, Smithard DG, Kalra L. Early assessments of dysphagia and aspiration risk in acute stroke patients. Stroke 2003;34:1252-1257.

86. Ertekin C, Aydogdu I, Yüceyar N, et al. Electrodiagnostic methods for neurogenic dysphagia. Electroencephalogr Clin Neurophysiol 1998;109:331-340.

87. O'Neill PA. Swallowing and prevention of complications. Br Med Bull 2000;56:457-465.

88. Yang SN, Pyun SB, Kim HJ, Ahn HS, Rhyu BJ. Effectiveness of noninvasive brain stimulation in dysphagia subsequent to stroke: A systemic review and meta-analysis. Dysphagia 2015;30:383-391.

89. Carnaby G, Hankey GJ, Pizzi J. Behavioural intervention for dysphagia in acute stroke: A randomised controlled trial. Lancet Neurol 2006;5:31-37.

90. Lin LC, Wang SC, Chen SH, Wang TG, Chen MY, Wu SC. Efficacy of swallowing training for residents following stroke. J Adv Nurs 2003;44:469-478.

91. Doggett DL, Tappe KA, Mitchell MD, Chapell R, Coates V, Turkelson CM. Prevention of pneumonia in elderly stroke patients by systematic diagnosis and treatment of dysphagia: an evidence-based comprehensive analysis of the literature. Dysphagia 2001;16:279-295.
92. Brady M, Furlanetto D, Hunter RV, Lewis, S, Milne V. Staff-led interventions for improving oral hygiene in patients following stroke. Cochrane Database Syst Rev 2006:CD003864.

93. Sorensen RT, Rasmussen RS, Overgaard K, Lerche A, Johansen AM, Lindhardt T. Dysphagia screening and intensified oral hygiene reduce pneumonia after stroke. J Neurosci Nurs 2013;45:139-146.

94. Teismann IK, Suntrup S, Warnecke T, et al. Cortical swallowing processing in early subacute stroke. BMC Neurol 2011;11:34.

95. 95. Barer DH. The natural history and functional consequences of dysphagia after hemispheric stroke. J Neurol Neurosurg Psychiatry 1989;52:236-241.

96. Yamada SM. Too early initiation of enteral nutrition is not nutritionally advantageous for comatose acute stroke patients. J Nippon Med Sch 2015;82:186-192.

97. Kattelmann KK, Hise M, Russell M, Charney P, Stokes M, Compher C. Preliminary evidence for a medical nutrition therapy protocol: enteral feedings for critically ill patients. J Am Diet Assoc 2006;106:12261241.

98. Anastasilakis CD, Ioannidis O, Gkiomisi AI, Botsios D. Artificial nutrition and intestinal mucosal barrier functionality. Digestion 2013;88:193-208.

99. Wirth R, Smoliner C, Jager M, Warnecke T, Leischker AH, Dziewas R; DGEM Steering Committee. Guideline clinical nutrition in patients with stroke. Exp Transl Stroke Med 2013;5:14.

100. Casaubon LK, Boulanger JM, Glasser E, et al. Canadian Stroke Best Practice Recommendations: Acute Inpatient Stroke Care Guidelines, Update 2015. Int J Stroke 2016;11:239-252.

101. Strong RM, Condon SC, Solinger MR, Namihas BN, Ito-Wong LA, Leuty JE. Equal aspiration rates from postpylorus and intragastric-placed smallbore nasoenteric feeding tubes: a randomized, prospective study. JPEN J Parenter Enteral Nutr 1992;16:59-63.

102. Spain DA, DeWeese RC, Reynolds MA, Richardson JD. Transpyloric passage of feeding tubes in patients with head injuries does not decrease complications. J Trauma 1995;39:1100-1102.

103. Jabbar A, McClave SA. Pre-pyloric versus post-pyloric feeding. Clin Nutr 2005;24:719-726.

104. Beavan J, Conroy SP, Harwood R, et al. Does looped nasogastric tube feeding improve nutritional delivery for patients with dysphagia after acute stroke? A randomised controlled trial. Age Ageing 2010;39:624-630.

105. Kostadima E, Kaditis AG, Alexopoulos EI, Zakynthinos E, Sfyras D. Early gastrostomy reduces the rate of ventilator-associated pneumonia in stroke or head injury patients. Eur Respir J 2005;26:106-111.

106. Bankhead R, Boullata J, Brantley S, et al. Enteral nutrition practice recommendations. JPEN J Parenter Enteral Nutr 2009;33:122-167.

107. Cunningham JJ. Calculation of energy expenditure from indirect calorimetry: assessment of the Weir equation. Nutrition 1990;6:222-223.

108. Headley JM. Indirect calorimetry: a trend toward continuous metabolic assessment. AACN Clin Issues 2003;14:155-167.

109. Strong RM, Condon SC, Solinger MR, Namihas BN, Ito-Wong LA, Leuty JE. Equal aspiration rates from postpylorus and intragastric-placed smallbore nasoenteric feeding tubes: a randomized, prospective study. JPEN J Parenter Enteral Nutr 1992;16:59-63.

110. Boullata J, Williams J, Cottrell F, Hudson L, Compher C. Accurate determination of energy needs in hospitalized patients. J Am Diet Assoc 2007;107:393-401.

111. Keçecioğlu S. Enteral beslenme ürünleri, seçim ve kullanım alanları. Güncel Gastroenteroloji 1998:258-268.

112. Lochsa H, Allisonb SP, Meierc R, et al. Introductory to the ESPEN Guidelines on Enteral Nutrition: Terminology, Definitions and General Topics. Clin Nutr 2006;25:180-186.

113. American Society for Parenteral and Enteral Nutrition (A.S.P.E.N.) Board of Directors. Clinical guidelines for the use of parenteral and enteral nutrition in adult and pediatric patients. JPEN J Parenter Enteral Nutr 2009;33:255259.

114. Steevens EC, Lipscomb AF, Poole GV, Sacks GS. Comparison of continuous vs intermittent nasogastric enteral feeding in trauma patients: perceptions and practice. Nutr Clin Pract 2002;17:118-122. 
115. Ciocon JO, Galindo-Ciocon DJ, Tiessen C, Galindo D. Continuous compared with intermittent tube feeding in the elderly. JPEN J Parenter Enteral Nutr 1992;16:525-528.

116. Coben RM, Weintraub A, Di Marino AJ Jr, Cohen S. Gastroesophageal reflux during gastrostomy feeding. Gastroenterology 1994;106:13-18.

117. Williams TA, Leslie GD. A review of the nursing care of enteral feeding tubes in critically ill adults: Part I. Intensive Crit Care Nurs 2004;20:330-343.

118. Rowat A. Enteral tube feeding for dysphagic stroke patients. Br J Nurs 2015;24:138.

119. Kuppinger DD, Rittler P, Hartl WH, Rüttinger D. Use of gastric residual volume to guide enteral nutrition in critically ill patients: A brief systematic review of clinical studies. Nutrition 2013;29:1075-1079.

120. Reigner J, Mercier E, Le Gouge A, et al. Effect of not monitoring residual gastric volume on risk of ventilator-associated pneumonia in adults receiving mechanical ventilation and early enteral feeding: a randomized controlled trial. JAMA 2013;309:249-256.

121. Montejo JC, Minambres E, Bordeje L, et al. Gastric residual volume during enteral nutrition in ICU patients: the REGANE study. Intensive Care Med 2010;36:1386-1393.

122. Pinilla JC, Samphire J, Arnold C, Liu L, Thiessen B. Comparison of gastrointestinal tolerance to two enteral feeding protocols in critically ill patients: a prospective, randomized controlled trial. JPEN J Parenter Enteral Nutr 2001;25:81-86

123. McClave SA, DeMeo MT, DeLegge MH, et al. North American summit on aspiration in the critically ill patient: consensus statement. JPEN J Parenter Enteral Nutr 2002;26(Suppl 6):80-85.

124. Prabhakaran S, Doraiswamy VA, Nagaraja V, et al. Nasoenteric tube complications. Scand J Surg 2012;101:147-155.

125. Acosta Escribano J, Herrero Meseguer I, Conejero García-Quijada R; Metabolism and Nutrition Working Group of the Spanish Society of Intensive Care Medicine and Coronary units. Guidelines for specialized nutritional and metabolic support in the critically-ill patient. Update. Consensus SEMICYUC-SENPE: Neurocritical patient. Nutr Hosp 2011;26(Suppl 2):72-75.

126. Hede GW, Faxén-Irving G, Olin AÖ, Ebbeskog B, Crisby M. Nutritional assessment and post-procedural complications in older stroke patients after insertion of percutaneous endoscopic gastrostomy a retrospective study. Food Nutr Res 2016;60:30456.

127. Gorzoni ML, Torre AD, Pires SL. Drugs and feeding tubes. Rev Assoc Med Bras (1992) 2010;56:17-21.

128. Boullata JI. Drug administration through an enteral feeding tube. Am J Nurs 2009;109:34-42.
129. Wohlt PD, Zheng L, Gunderson S, Balzar SA. Recommendations for the use of medications with continuous enteral nutrition. Am J Health-Syst Pharm 2009;66:1458-1467.

130. Williams NT. Medication administration through enteral feeding tubes. Am J Health-Syst Pharm 2008;65:2347-2357.

131. Matysiak-Luśnia K, Lysenko L. Drug administration via enteral feeding tubes in intensive therapy - terra incognita? Anaesthesiol Intensive Ther 2014; $46: 307-311$.

132. Phillips NM, Nay R. Nursing administration of medication via enteral tubes in adults: a systematic review. Int J Evid Based Healthc 2007;5:324353.

133. Peterson JJ, Hoehns JD. Administration of direct oral anticoagulants through enteral feeding tubes. J Pharm Technol 2016;32:196-200.

134. Cawood AL, Elia M, Stratton RJ. Systematic review and meta-analysis of the effects of high protein oral nutritional supplements. Ageing Res Rev 2012;11:278-296.

135. Stratton RJ, Ek AC, Engfer M, et al. Enteral nutritional support in prevention and treatment of pressure ulcers: a systematic review and metaanalysis. Ageing Res Rev 2005;4:422-450.

136. Bourdel-Marchasson I, Barateau M, Rondeau V, et al. A multi-center trial of the effects of oral nutritional supplementation in critically ill older inpatients. GAGE Group. Groupe Aquitain Geriatrique d'Evaluation. Nutrition 2000;16:1-5.

137. Milne AC, Avenell A, Potter J. Meta-analysis: Protein and energy supplementation in older people. Ann Intern Med 2006;144:37-48.

138. Milne AC, Potter J, Vivanti A, Avenell A. Protein and energy supplementation in elderly people at risk from malnutrition. Cochrane Database Syst Rev 2009; 15:CD003288.

139. Rabadi MH, Coar PL, Lukin M, Lesser M, Blass JP. Intensive nutritional supplements can improve outcomes in stroke rehabilitation. Neurology 2008;71:1856-1861.

140. Kreymann KG, Berger MM, Deutz NE, et al. ESPEN Guidelines on Enteral Nutrition: Intensive care. Clin Nutr 2006;25:210-223.

141. Singer P, Berger MM, Van den Berghe G, et al. ESPEN Guidelines on Parenteral Nutrition: intensive care. Clin Nutr 2009;28:387-400.

142. McClave SA, Taylor BE, Martindale RG, et al. Guidelines for the Provision and Assessment of Nutrition Support Therapy in the Adult Critically Ill Patient: Society of Critical Care Medicine (SCCM) and American Society for Parenteral and Enteral Nutrition (A.S.P.E.N.). JPEN J Parenter Enteral Nutr 2016;40:159-211. 
Annex 1. Clinical swallowing assessment (Logemann) which can be used in stroke patients

Clinical swallowing assessment

\begin{tabular}{|c|c|c|}
\hline & Safe & Not safe \\
\hline \multicolumn{3}{|l|}{ Medical history } \\
\hline \multicolumn{3}{|l|}{ 1. Recurrent pneumonia } \\
\hline \multicolumn{3}{|l|}{ 3. Aspiration pneumonia } \\
\hline \multicolumn{3}{|c|}{ 4. Long-term intubation ( $>1$ week) or tracheotomy (>6 weeks) } \\
\hline \multicolumn{3}{|l|}{ 5. Alertness/awareness } \\
\hline \multicolumn{3}{|l|}{ 6. Cooperation/agitation } \\
\hline \multicolumn{3}{|l|}{ 7. Attention/communication level } \\
\hline \multicolumn{3}{|l|}{ 8. Awareness of swallowing problem } \\
\hline \multicolumn{3}{|l|}{ 9. Awareness of secretions } \\
\hline \multicolumn{3}{|l|}{ 12. Fatigue } \\
\hline \multicolumn{3}{|l|}{ Oral motor tests } \\
\hline \multicolumn{3}{|l|}{ 13. Oral, pharyngeal, laryngeal anatomy and function } \\
\hline \multicolumn{3}{|l|}{ 14. Level of obeying orders } \\
\hline \multicolumn{3}{|l|}{ 15. Dysarthria } \\
\hline \multicolumn{3}{|l|}{ 16. Facial weakness } \\
\hline \multicolumn{3}{|l|}{ 17. Oral apraxia } \\
\hline \multicolumn{3}{|l|}{ 18. Oral sensation } \\
\hline \multicolumn{3}{|l|}{ 24. Coughing and throat cleaning } \\
\hline \multicolumn{3}{|l|}{ 25. Delayed pharyngeal swallowing } \\
\hline \multicolumn{3}{|l|}{ 26. Decreased laryngeal elevation } \\
\hline 27. Wheezing voice & & \\
\hline 28. More than one swallowing trial for one bolus & & \\
\hline
\end{tabular}


Annex 2. Important characteristics for some orally administered drugs in stroke patients with tube feeding

\begin{tabular}{|c|c|c|}
\hline Drug & Observation & Alternative \\
\hline Atenolol & Inadequate plasma concentration & IV esmolol \\
\hline Amiodarone & Very low plasma concentration & IV amiodarone \\
\hline Ciprofloxacin & $\begin{array}{l}\text { Plasma level cannot be estimated } \\
\text { Chelation with enteral product }(27-67 \%)\end{array}$ & $\begin{array}{l}\text { IV ciprofloxacin } \\
\text { Twice the dose }\end{array}$ \\
\hline $\begin{array}{l}\text { Lansoprazole, } \\
\text { Omeprazole }\end{array}$ & $\begin{array}{l}\text { No stability of gastric acidity } \\
\text { Bioavailability decreased by } 33-39 \%\end{array}$ & $\begin{array}{l}\text { Pantoprazole } \\
\text { +bicarbonate }\end{array}$ \\
\hline IV: Intravenous & & \\
\hline
\end{tabular}

\begin{tabular}{|c|c|}
\hline Drug & Observation \\
\hline Clopidogrel & 300 mg loading given via NG tube provides more rapid and higher bioavailability than by oral route \\
\hline Amlodipine & Since it is rapidly denatured after crushing and diluting, it should be administered rapidly \\
\hline Aspirin & $\begin{array}{l}\text { Although enteric tablets are crushed, they may not be completely absorbed in the stomach. No need for fear of } \\
\text { gastric side effects }\end{array}$ \\
\hline $\begin{array}{l}\text { Carbidopa } \\
+ \text { L-dopa }\end{array}$ & Case reports indicating it is effective in the perioperative period \\
\hline Duloxetine & Tablet dissolves when mixed with apple juice and it provides as much effective blood level as capsules \\
\hline Warfarin & $\begin{array}{l}\text { It sticks to the feeding tube, so } 35 \% \text { of the dose reaches stomach. Dose should be reduced when feeding is } \\
\text { switched to oral route }\end{array}$ \\
\hline Dabigatran & Cannot be placed down an enteral feeding tube \\
\hline Rivaroxaban & May also be given to patients via feeding tube if the tube is placed within the stomach \\
\hline Apixaban & Crushed forms suspended in distilled water can be administered via a feeding tube \\
\hline Epdantoin & $89 \%$ is adsorbed. It should be well-diluted. It binds to proteins in nutritional products and calcium salts ( \pm 2 hours) \\
\hline L-dopa & $\begin{array}{l}\text { Its absorption decreases when protein amount increases above } 1.4 \mathrm{~g} / \mathrm{kg} / \text { day. It is not administered by continuous } \\
\text { infusion }\end{array}$ \\
\hline
\end{tabular}


Annex 3. Algorithm for the approach to patient with stroke in the acute and chronic phases

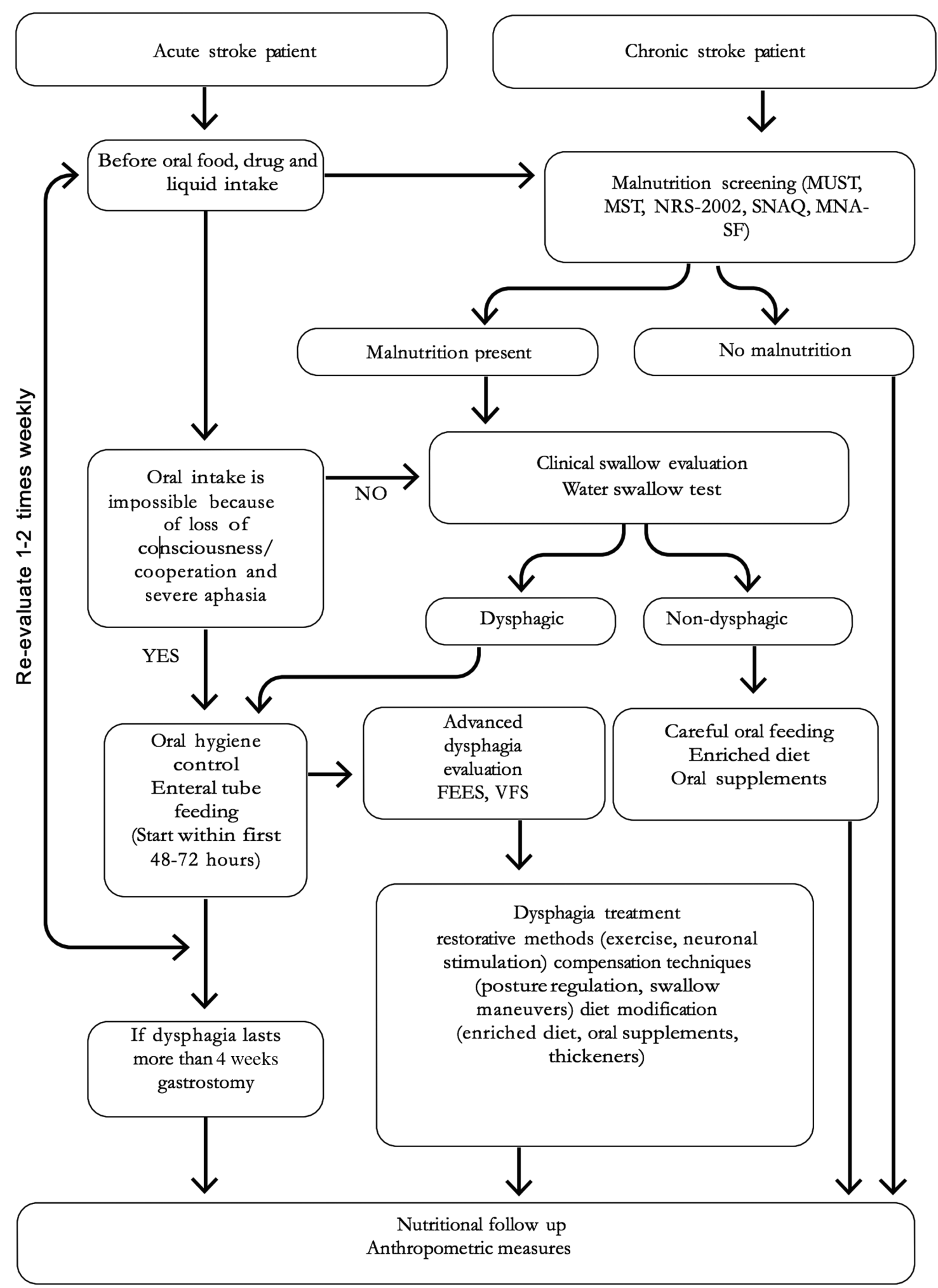

MUST: Malnutrition Universal Screening Test, MST: Malnutrition Screening Tool, NRS-2002: Nutrition Risk Screen-2002, SNAQ: Short Nutrition Assessment Questionnaire, MNA-SF: Mini Nutrition Assessment-Short Form, VFS: Videofluoroscopy, FEES: Fiberoptic endoscopic evaluation 
Annex 4. Basic requirements in enteral nutrition

Basic requirements in enteral nutrition
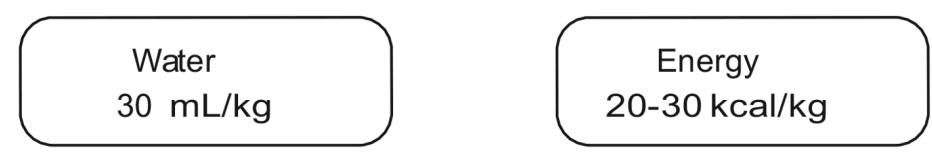

Protein

$1.0-1.5 \mathrm{gr} / \mathrm{kg}$

Initial infusion rate $20 \mathrm{~mL} / \mathrm{hour}$

Infusion rate is increased to $10-20 \mathrm{~mL} /$ hour at $8-12$ hours interims it is expected to reach nutritional goals within $48-72$ hours

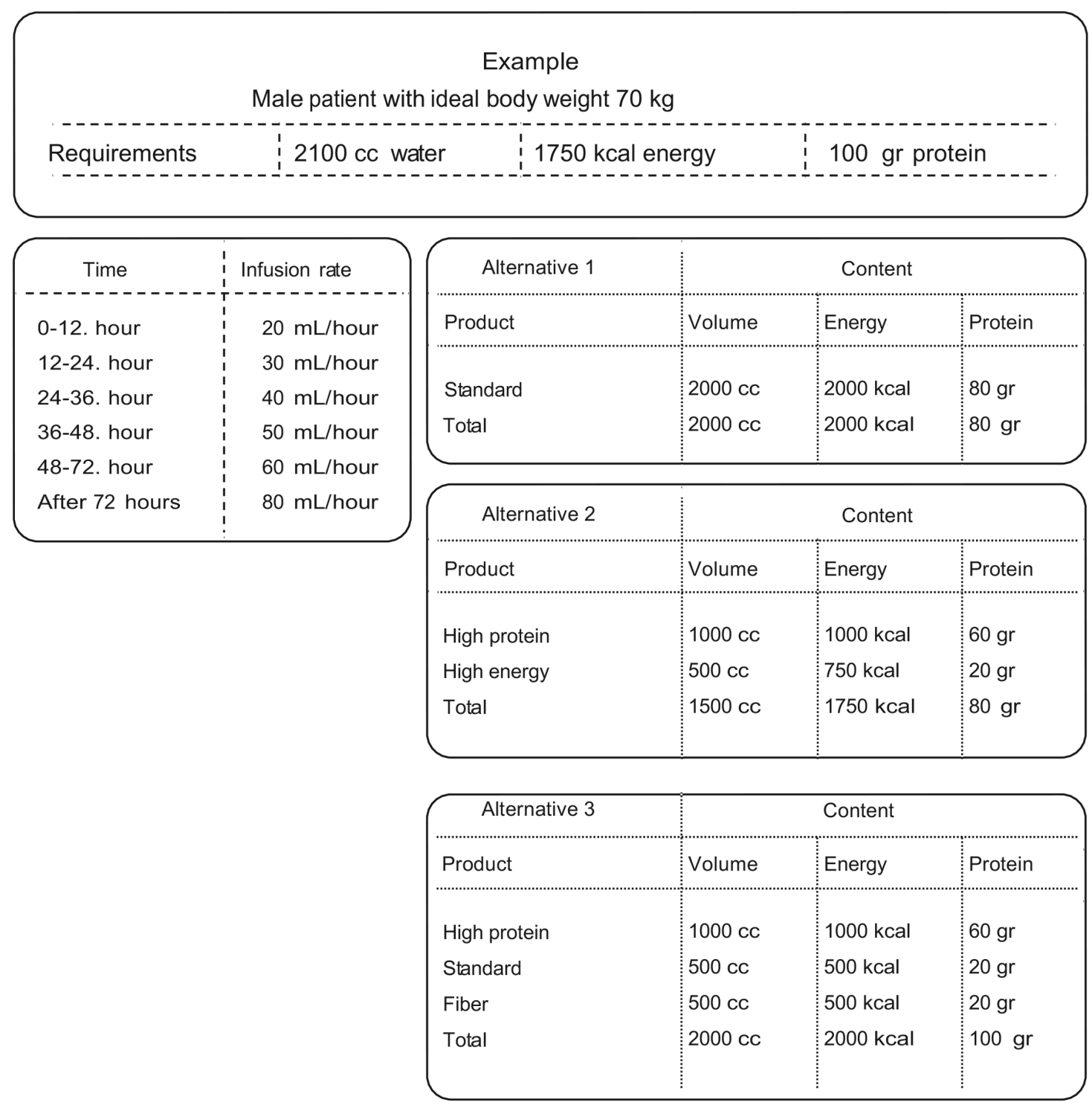

